\title{
Scientometric Analysis of Corporate Social Responsibility, Corporate Social Performance and Financial Performance Based on Corporate Governance
}

\author{
Chung-Lien $\mathrm{Pan}^{1 *}$, Lin $\mathrm{Yu}^{1}$, Zhuoshan $\mathrm{Lin}^{1}$, Jialong Li ${ }^{1}$, Yu-Chun Pan ${ }^{2}$ \\ ${ }^{1}$ Nanfang College of Sun Yat-sen University, School of Accounting, Guangzhou, Guangdong \\ ${ }^{2}$ National Taiwan University of Science and Technology Graduate Institute of Finance, Taipei Taiwan
}

\begin{abstract}
The economic growth and social responsibility of the company have become hot topics of concern to society. Fulfilling a company's obligations of social responsibility can establish a good corporate image and benefit the company's long-term development. Tracking the research fronts in this field can help to understand the hotspots that scholars pay attention to and fill the gaps in the field. We used the scientometric analysis to explore corporate governance research from 1987 to 2020 based on the Web of Science (WoS) database. Our research shows that corporate social responsibility focus on topics such as sustainability, social responsibility, and shareholders, and financial performance will be more skewed towards financial crisis, company value, and other research. The main publications are the Journal of Business Ethics and Corporate Governance-An International Review. The increase in the number of publications and citations reflects the strong interest of scholars in this research area. In this area, the organizations of developed countries are dominant, especially the United States, and China has the largest number of funding agencies, suggests that the economic powers are paying more attention to the literature on economic management. However, corporate social performance articles are relatively small, and strengthening this area can become a future research direction.
\end{abstract}

\section{INTRODUCTION}

Under the influence of the sustainable economic development concept and the attention of the government and society, companies have paid more attention to social responsibility. Financial Performance (FP), Corporate Social Performance (CSP), and Corporate Social Responsibility (CSR) have become hotspots of corporate governance. Global perspectives for private companies: Agility in changing markets report released by Deloitte (2019), which mentioned that $66 \%$ of private enterprises regard social responsibility as the most important or very important issue. Incorporate social responsibility into company strategy and branding for talent and customers to gain a greater competitive advantage [1]. Sina Finance and the Green Finance International Research Institute of the Central University of Finance and Economics (2019) released the China ESG White Book, which shows that "Environment, Social Responsibility, Corporate Governance" (ESG) can disclose information other than financial information, such as related environmental performance, social responsibility, and corporate governance factors. More investors include ESG standards in the investment selection process and focus on long-term return on investment and positive social impact [2]. 2030 Strategy: Mainstreaming the urgency to action for sustainable impact released by CSR Europe's (2020) expresses the vision of Responsible Business, Better Future, and aims to decouple economic development from environmental degradation [3]. Porter (2011) shows that combining corporate responsibility with business strategy is the source of future new competitiveness for enterprises [4]. Jo \& Har joto (2011) concluded that CSR participation in corporate governance has a positive impact on FP [5]. Stanwick \& Stanwick (2013) examined the relationship between CSP and three organizational variables: organizational size, financial performance, and environmental performance. The results of the study showed that corporate size, financial performance, and environmental performance have an impact on corporate social performance [6]. Compared with the isolated literature in the past, it is more valuable to study the network links of financial performance, corporate social responsibility, and corporate social performance. This article collected 1,072 articles from the Web of Science (WoS) for a scientometric analysis of the literature. It focuses on describing the latest trends in the field of corporate governance since 1987 and summarizes the research fronts between disciplines by visualizing images. These results will provide scholars with an understanding of scientific research developments in various fields, and provide important references and research directions for tracking frontier fields.

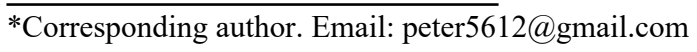




\section{DATA AND METHODS}

To explore the dynamics of the social science literature in the field of corporate governance, we collected the relevant paper from the WoS database using the following dictionary, which was selected from the Oxford bibliography [7].

TS = ("Financial Performance" OR "Corporate Social Responsibility" OR "CSR" OR "Corporate Social Performance" OR "CSP") AND TS = ("Corporate Governance") AND SU = ("Business \& Economics" OR "Government \& Law" OR "Social Sciences" OR "Management" OR "Communication" OR "Technology")

A total of 1,072 articles were collected on February 16, 2020 (including SCI-EXPANDED and SSCI). We used the VOSviewer and Python package for mapping.

\section{RESEARCH FINGDINGS}

As shown in Figure 1, the number of publications has shown a rising and fluctuating trend since 2005. In Figure 2 , appearing a steady upward trend, which shows that scholars in the field of management have always regarded these topics as long-term researchable areas.

\subsection{Annual Trends}

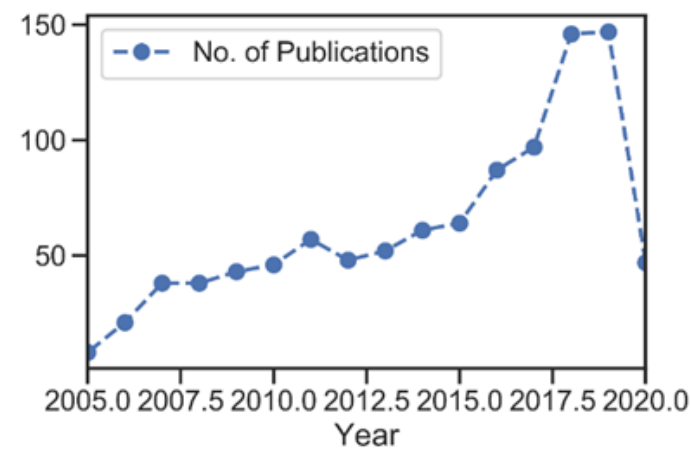

Figure1. Annual publications trend from 2005 to 2020

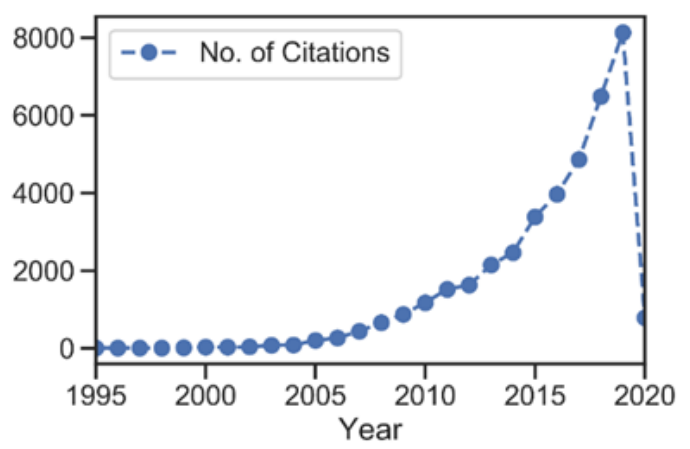

Figure2. Annual citations trend from 1995 to 2019

\subsection{Main Institutions and Funding Agencies}

Table 1 lists the top 10 organizations, which involves the presence of the USA, Canada, and Spain organizations such as State University System of Florida, Pennsylvania Commonwealth System of Higher Education Pcshe, York University Canada, University of Salamanca, etc. Besides, the Italian and Dutch ones such as Bocconi University have also mentioned. Table 2 shows the top 10 Funding Agencies, indicating the major funding agencies are official, covering the National Natural Science Foundation of China, Ministry of Science and Technology Taiwan, the Spanish Ministry of Economy Industry and Competitiveness, Australian Research Council, etc.

TABLE I. TOP 10 ORGANIZATIONS

\begin{tabular}{cr}
\hline Organizations & NO. of Articles \\
\hline State University System of Florida & 25 \\
University of Salamanca & 20 \\
Pennsylvania Commonwealth System of Higher & \\
Education Pcshe & 19 \\
York University Canada & 17 \\
Pennsylvania State University & 16 \\
Arizona State University & 15 \\
Bocconi University & 15 \\
University of Texas System & 14 \\
Concordia University Canada & 13 \\
Erasmus University Rotterdam & 13 \\
University of Illinois System & 13 \\
\hline
\end{tabular}

TABLE II. TOP 10 FUNDING AgENCIES

\begin{tabular}{|c|c|}
\hline Funding Agencies & $\begin{array}{l}\text { NO. of } \\
\text { Articles }\end{array}$ \\
\hline National Natural Science Foundation of China & 22 \\
\hline Ministry of Science and Technology Taiwan & 8 \\
\hline \multicolumn{2}{|l|}{ Spanish Ministry of Economy Industry and } \\
\hline Competitiveness & 7 \\
\hline Australian Research Council & 5 \\
\hline European Union Eu & 5 \\
\hline Social Sciences and Humanities Research Council of & \\
\hline Canada Sshrc & 5 \\
\hline Fundamental Research Funds for the Central Universities & 4 \\
\hline Ministry of Education China & 4 \\
\hline Ministry of Science and Innovation & 4 \\
\hline Spanish Ministry of Economy and Competitiveness & 4 \\
\hline Basque Government & 3 \\
\hline
\end{tabular}

\subsection{Main Clusters of Author Keywords and Sources}

To further discuss the co-citation and co-cited of the papers with FP, CSR, and CSP under corporate governance, and their respective research hotspots. We used the first 29 author keywords processed by the thesaurus compiled by experts. For example, belong to the same field (CSR and corporation social responsibility) or similar words (boards of directors and board of directors).

We calculate the number of occurrences and generates a co-occurrence network based on author keywords and publication sources data. The keywords mapping is shown in Figure 3 and Figure 4.

- $\quad$ Red "financial performance" cluster

The first cluster is centered on "corporate governance", and "financial performance" is directly related to it. From Figure 3, we find that the weights of "financial performance", "company performance", and "agent 
theory" are relatively large, occupying major positions [813]. Focusing on the "financial performance" module, the topics related to "family firms", "ownership structure", "firm value", and "financial crisis" are hot topics for scholars to discuss. It shows that with the development of the company, agency issues, financial crisis, and company value or performance that arise from the process of moving from a family business to a professional management system have always been the main focus of corporate governance in the industry, government, and academia.

- $\quad$ Green "csr" cluster

The second cluster is centered on csr, which is most closely related to corporate governance $[14,15]$. In recent years, with the increasing emphasis on the concept of green environmental protection, the themes related to the concept of green economic development in the picture include the topics of "sustainability", "social responsibility", and "disclosure." It shows that while the economy is developing rapidly, in addition to maximizing profits, the company must also give back to the society, assume social responsibilities such as protecting the environment and disclosing reports on sustainable development, and work towards sustainable development. For the responsibility of shareholders and other stakeholders, scholars have focused on areas such as "shareholder incentives", "institutional theory" and "business ethics".

- Yellow " csp " cluster

The third cluster focuses on "csp". Compared to FP and CSR, scholars rarely discuss this topic, but it plays a crucial intermediary role, as shown in Figure 3, connecting " "corporate governance" and "csr" two core clusters. Regarding "earnings management", it is directly related to the csp, and it also links the green cluster and the red cluster set [16].

- Blue "board of director" cluster

The fourth cluster is based on the central theme of "board of director" derived from the field of corporate governance and discusses gender (conceptual issues such as quotas, policies, and management), gender diversity, and diversity (ethnicity and ethics) and associate with "board independence". In practice, to strengthen the function of the board of directors, the management hopes that the diversity of the supervisors will prove the company's efforts on the topic of corporate governance, so that management can get on track.

- $\quad$ Purple "stakeholder theory" cluster

In the fifth cluster, the "shareholder theory" has a larger weight, which is related to "shareholder incentives". It can be explained on the side that scholars will also include "shareholder theory" and "shareholder management" when discussing issues related to FP, CSR, and CSP. Because when the company is included in the CSR consideration, it may harm the performance of the company on FP and CSP, which are related to the rights and interests of shareholders.

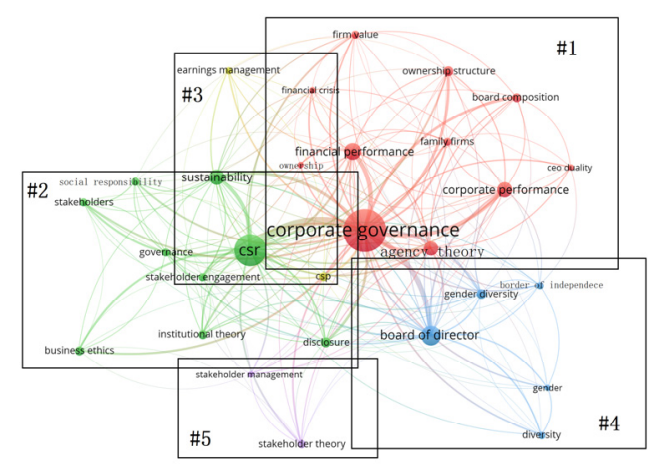

Figure3. A map based on author keyword co-occurrence network: clustered outcomes

\subsection{Main Clusters of Sources}

Figure 4 reveals the distribution of journals published in FP, CSR and CSP related to corporate governance, divided into five journal clusters. The red cluster shows the top publication sources centered on the Journal of Business Ethics, which connected to Sustainability, Corporate Social Responsibility and Environmental Management, and Journal of Cleaner Production. The green cluster is centered on Corporate Governance-An International Review and is related to top publications such as Strategic Management Journal, Journal of Management Research, Journal of Business Research, British Journal of Management, Academy of Management Journal Link. The blue cluster is mainly based on the Journal of Corporate Finance, showing the source of top publications such as the Journal of Corporate Finance, Emerging Markets Finance and Trade and Journal of Banking \& Finance. The yellow cluster is Management Decision and the purple cluster is Business \& Society. They play an intermediary role and connect the top journals.

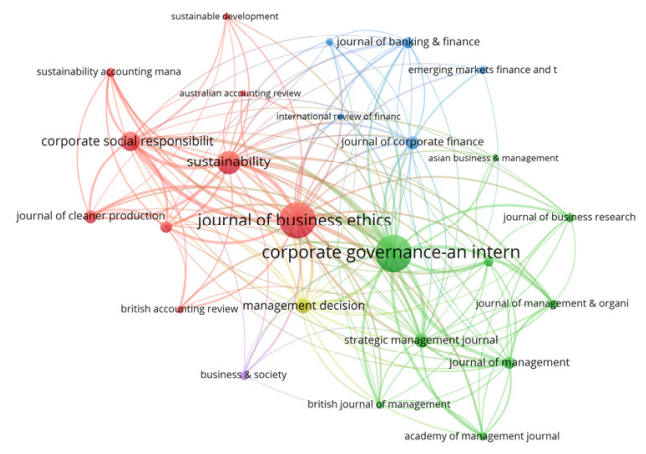

Figure4. Top publication sources: a bibliographic coupling relationship network visualization

\section{CONCLUSION}

The purpose of this paper is to understand the current research fronts of FP, CSR, CSP and derivative topics in the field of corporate governance. Through the scientific 
and systematic literature review, these statistics table can provide insight into the distribution of top institutions and funding organizations. For the aim of further exploration, this paper also conducted cluster analysis and found that the CSR literature has the largest weight, which represents that when companies pursue performance on FP and CSP, they should even consider CSR to meet the expectations of society.

Through the analysis of these clusters, we found that the research direction of scholars coincides with the focus of corporate governance in reality. At the same time, CFP articles are relatively small, and strengthening this area can become a future research direction.

\section{REFERENCES}

1. Deloitte.(2019) Global perspectives for private companies: Agility in changing markets. Retrieved from:https://www2.deloitte.com/content/dam/Deloitt e/cn/Documents/deloitte-private/deloitte-cn-privateperspectives-for-private-companies-zh-190606.pdf

2. Sina Finance and Green Finance International Research Institute of Central University of Finance and Economics.(2019) CHINA ESG WHITE BOOK[white book]Retrieved from:finance.sina.com.cn/esg/other/whitebook.shtml

3. CSR Europr.(2019) 2030 Strategy: Mainstreaming the urgency to action for sustainable impact. Retrieved from: https://www.csreurope.org/sites/default/files/CSR E 2030 Strategy Brochure_0.pdf

4. Porter, M. E., \& Kramer, M. R. (2019). Creating shared value. In Managing sustainable business (pp. 323-346). Springer, Dordrecht.

5. Jo, H., \& Harjoto, M. A. (2012). The causal effect of corporate governance on corporate social responsibility. Journal of business ethics, 106(1), 5372.

6. Stanwick, P. A., \& Stanwick, S. D. (1998). The relationship between corporate social performance, and organizational size, financial performance, and environmental performance: An empirical examination. Journal of business ethics, 17(2), 195204.

7. Anon Digital Literacy - Communication - Oxford Bibliographies - obo.

8. Carter, D. A., D'Souza, F., Simkins, B. J., \& Simpson, W. G. (2010). The gender and ethnic diversity of US boards and board committees and firm financial performance. Corporate Governance: An International Review, 18(5), 396-414.

9. Haniffa, R., \& Hudaib, M. (2006). Corporate governance structure and performance of Malaysian listed companies. Journal of Business Finance \& Accounting, 33(7-8), 1034-1062.

10. Francoeur, C., Labelle, R., \& Sinclair-Desgagné, B. (2008). Gender diversity in corporate governance and top management. Journal of business ethics, 81(1), 83-95.
11. Jackling, B., \& Johl, S. (2009). Board structure and firm performance: Evidence from India's top companies. Corporate Governance: An International Review, 17(4), 492-509.

12. Cornett, M. M., Marcus, A. J., Saunders, A., \& Tehranian, H. (2007). The impact of institutional ownership on corporate operating performance. Journal of Banking \& Finance, 31(6), 1771-1794.

13. Kacperczyk, A. (2009). With greater power comes greater responsibility? Takeover protection and corporate attention to stakeholders. Strategic Management Journal, 30(3), 261-285.

14. Brammer, S., Jackson, G., \& Matten, D. (2012). Corporate social responsibility and institutional theory: New perspectives on private governance. Socio-economic review, 10(1), 3-28.

15. Jo, H., \& Harjoto, M. A. (2011). Corporate governance and firm value: The impact of corporate social responsibility. Journal of business ethics, 103(3), 351-383.

16. Prior, D., Surroca, J., \& Tribó, J. A. (2008). Are socially responsible managers really ethical? Exploring the relationship between earnings management and corporate social responsibility. corporate governance: An international review, 16(3), 160-177. 